\title{
AMIGO2 wt Allele
}

National Cancer Institute

\section{Source}

National Cancer Institute. AMIGO2 wt Allele. NCI Thesaurus. Code C119684.

Human AMIGO2 wild-type allele is located in the vicinity of $12 q 13.11$ and is approximately $4 \mathrm{~kb}$ in length. This allele, which encodes amphoterin-induced protein 2 , is involved in both cell-cell adhesion and the inhibition of apoptosis. 